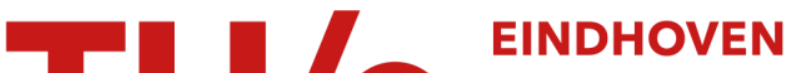 \\ UNIVERSITY OF \\ TECHNOLOGY
}

\section{Shear capacity as prognostic of nocturnal boundary layer regimes}

Citation for published version (APA):

van Hooijdonk, I., Donda, J., Bosveld, F., Moene, A., Clercx, H., \& van de Wiel, B. (2015). Shear capacity as prognostic of nocturnal boundary layer regimes. Paper presented at 15th European Turbulence Conference, ETC 2015, Delft, Netherlands.

Document status and date:

Published: 01/01/2015

\section{Document Version:}

Publisher's PDF, also known as Version of Record (includes final page, issue and volume numbers)

\section{Please check the document version of this publication:}

- A submitted manuscript is the version of the article upon submission and before peer-review. There can be important differences between the submitted version and the official published version of record. People interested in the research are advised to contact the author for the final version of the publication, or visit the $\mathrm{DOI}$ to the publisher's website.

- The final author version and the galley proof are versions of the publication after peer review.

- The final published version features the final layout of the paper including the volume, issue and page numbers.

Link to publication

\section{General rights}

Copyright and moral rights for the publications made accessible in the public portal are retained by the authors and/or other copyright owners and it is a condition of accessing publications that users recognise and abide by the legal requirements associated with these rights.

- Users may download and print one copy of any publication from the public portal for the purpose of private study or research.

- You may not further distribute the material or use it for any profit-making activity or commercial gain

- You may freely distribute the URL identifying the publication in the public portal.

If the publication is distributed under the terms of Article 25fa of the Dutch Copyright Act, indicated by the "Taverne" license above, please follow below link for the End User Agreement:

www.tue.nl/taverne

Take down policy

If you believe that this document breaches copyright please contact us at:

openaccess@tue.nl

providing details and we will investigate your claim. 


\title{
SHEAR CAPACITY AS PROGNOSTIC OF NOCTURNAL BOUNDARY LAYER REGIMES
}

\author{
Ivo van Hooijdonk ${ }^{1}$, Judith Donda ${ }^{1} \&$ Fred Bosveld ${ }^{2} \&$ Arnold Moene ${ }^{3} \&$ \\ Herman Clercx ${ }^{1} \&$ Bas van de Wiel ${ }^{1}$ \\ ${ }^{1}$ Eindhoven University of Technology, Eindhoven, Netherlands \\ ${ }^{2}$ Royal Netherlands Meteorological Institure (KNMI), De Bilt, Netherlands \\ ${ }^{3}$ Wageningen University, Wageningen, Netherlands
}

$\underline{\text { Abstract }}$ In some nights, the near-surface temperature can drop dramatically and turbulence in the stably stratified boundary layer becomes very weak, such that the lfow reaches a (quasi-) laminar state. In other cases, however, the atmosphere remains in a turbulent state and temperatures stay relatively high. Recently, the appearance of two distinct boundary layer regimes was explained by a new theoretical framework. This theory builds on the fact that the turbulent heat flux in stably stratified flow is limited to a maximum for given wind shear. This introduces a characteristic flux-based velocity scale, which can be used to predict the regimes. This hypothesis is consistent with field observations and numerical results. Also, the hypothesis is generalised to a dimensionless framework.

\section{INTRODUCTION}

After sunset a net emission of radiation causes the surface temperature to drop. As the surface cools the air from below, the atmospheric boundary layer becomes stably stratified. Weather models perform poorly under stratified conditions, leading to significant errors in the prediction of the near-surface temperature. At the same time, strongly stratified conditions favour fog formation, ground frost and pollution trapping. These prediction issues are symptoms of a lack of fundamental understanding of the transport processes under stably stratified conditions. While the laminar-to-turbulent transition can often be predicted by perturbation theory, no such techniques are possible for the return transition. In atmospheric flows, however, such transition frequently occurs.

In literature (e.g. [2]) nocturnal boundary layers that are characterised by weak turbulence and a strong temperature gradient are referred to as 'very stable boundary layers'. These conditions generally occur clear-sky and conditions with weak winds. If, on the other hand, winds are strong or under cloudy conditions, turbulence is generally continuous and relatively strong. This type is referred to as the 'weakly stable boundary layer'.

\section{CONCEPT}

Recently, a mechanism was proposed by [3, 4]. It is based on the fact that the turbulent heat flux (heat supply to the surface energy budget) is limited to a maximum. The occurrence of a maximum is readily understood from considering the limit behaviour: both for neutrally stratified conditions (no temperature gradient) and the strongly stratified limit (no vertical mixing) no vertical heat transport occurs. Thus a maximum must exist at an intermediate stability level. Here, the framework is both extended and tested against a large dataset, which covers more than 10 years of outdoor atmospheric data.

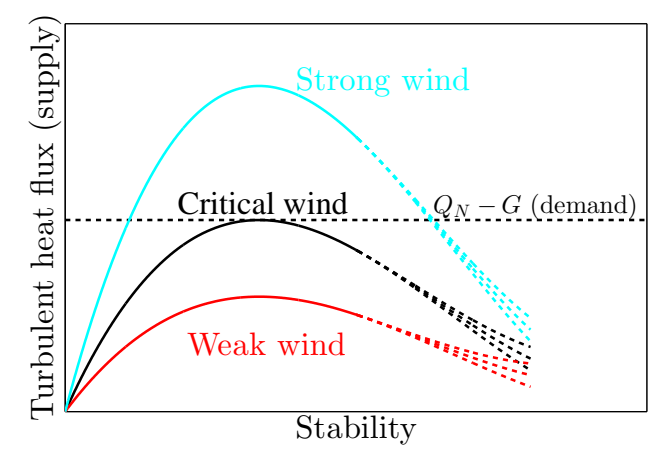

Figure 1. Conceptual sketch of the surface energy budget: net radiative emission correct for the ground heat flux is shown by the dashed black line. The ground heat flux slightly lowers the energy demand, but does not significantly alter the dynamics. The turbulent heat flux is shown for three wind speeds: strong wind speed (blue), weak wind speed (red) and the minimum wind speed (black). Originally presented in [5]. 
Figure 1 shows a sketch of turbulent heat flux for three different situations. In this figure the net radiation is shown as a constant energy demand (black dashed line). In the strong wind case (blue line) the maximum turbulent heat flux is larger than the energy loss by net radiation. As a result an equilibrium can be reached when the energy loss is exactly balanced by an equal energy supply. In this steady state the boundary layer is weakly stable. In case the wind is weaker (red line), no such equilibrium state can be found. The boundary layer then reaches a regime (right side of the maximum), where a positive feedback exists between increasing temperature gradient and decreasing energy supply. This situation can lead very low surface temperatures and suppressed levels of turbulence. At a certain wind speed the maximum turbulent heat flux coincides with heat demand at the surface. This critical state defines a characteristic (minimum) wind speed to sustain the weakly stable state.

\section{RESULTS}

Field observations from a large number of nights (approx. 4500) show consistent behaviour with this hypothesis. This set of nights is filtered for clear-sky cases (i.e. sufficient radiative emission). The clear-sky cases are subdivided into groups of approx. $50-150$ nights with similar wind speeds. The observations support the existence of the two fundamentally different regimes: weakly stable nights exhibit a turbulent steady state. In contrast, during the first hours of very stable nights, turbulence is in a transient state with much lower intensity. The theoretical prediction of the transition towards weak turbulence appears to work well for the ensemble averaged observations.

A new parameter, Shear Capacity, is introduced which compares actual wind speed to a theoretical minimum wind speed ([5]). This parameter outperforms classically used regime predictors (Richardson number and Obukhov length) in predicting the transition to another flow regime, i.e. weakly stable to very stable (figure 2 ).

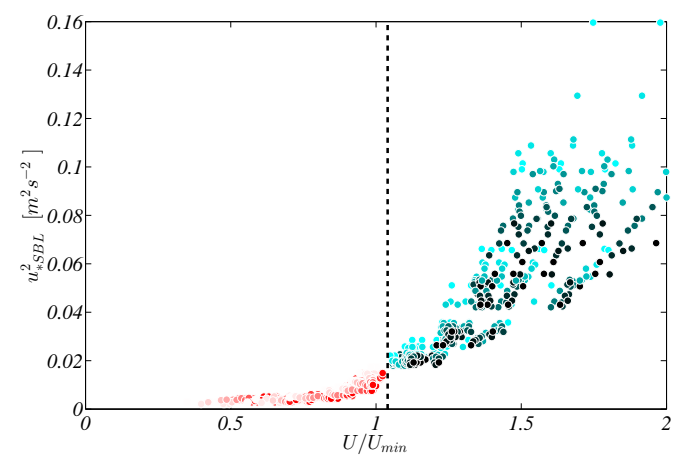

Figure 2. This figure shows the near-surface turbulent momentum flux as a function of the normalised wind speed. For weak wind cases (red shades) turbulence is very weak. The blue shades indicate nights with relatively strong turbulence. Each point represents an average of approx. $50-100$ different nights. The vertical dashed line signifies the division made by the normalisation. Originally presented in [5].

Further theoretical analysis shows that is impossible for the traditional parameters to make such distinction. Shear Capacity, however, appears the right normalisation to build a dimensionless theoretical framework to generalise the hypothesis of $[3,4]$. The fact that both results from atmospheric flows as well as theoretical model analysis point in the same direction, indicates that the Shear Capacity is a suitable indicator of this turbulent-to-laminar transition. This is corroborated by the numerical results of [1] as well as our own preliminary numerical simulations (direct numerical simulation).

\section{References}

[1] J. Donda, B.J.H. van de Wiel, I.G.S. van Hooijdonk, A. Moene, H. Jonker, G.J.F. van Heijst, and H.J.H. Clercx. Collapse of turbulence in stably stratified channel flow: a transient phenomenon. Quarterly Journal of the Royal Meteorological Society, Accepted, 2015. Quarterly Journal of the Royal Meteorological Society.

[2] L. Mahrt. Stratified atmospheric boundary layers and breakdown of models. Theoretical and Computational Fluid Dynamics, 11:263-279, 1998.

[3] B.J.H. van de Wiel, A.F. Moene, and H.J.J. Jonker. The cessation of continuous turbulence as precursor of the very stable nocturnal boundary layer. Journal of the Atmospheric Sciences, 69:3097-3115, 2012.

[4] B.J.H. van de Wiel, A.F. Moene, H.J.J. Jonker, P. Baas, S. Basu, J.M.M Donda, J. Sun, and A.A.M Holtslag. The minimum wind speed for sustainable turbulence in the nocturnal boundary layer. Journal of the Atmospheric Sciences, 69:3116-3127, 2012.

[5] I.G.S. van Hooijdonk, J.M.M. Donda, F.C. Bosveld, H.J.H. Clercx, and B.J.H. van de Wiel. Shear capacity as prognostic of nocturnal boundary layer regimes. Journal of the Atmospheric Sciences, in press, 2015. 